\title{
Exploring the Dark Side of Tax Policy: An Analysis of the Interactions between Fiscal Illusion and the Shadow Economy
}

\author{
Andreas Buehn \\ Roberto Dell' Anno \\ Friedrich Schneider
}

CESIFO WORKING PAPER NO. 5466

CAtegory 2: Public Choice

August 2015

An electronic version of the paper may be downloaded

- from the SSRN website:

- from the RePEc website:

- from the CESifo website:

wWw.SSRN.com

Www.RePEc.org

www.CESifo-group.org/wp 


\title{
Exploring the Dark Side of Tax Policy: An Analysis of the Interactions between Fiscal Illusion and the Shadow Economy
}

\begin{abstract}
This paper presents an empirical analysis of the relationship between fiscal illusion and the shadow economy for 104 countries over the period 1989-2009. We argue that both unobservable phenomena are closely linked to each other, as the creation of a fiscal illusion may be helpful if governments want to control shadow economic activities. Using a MIMIC model with two latent variables we confirm previous findings on the driving forces of the shadow economy and identify the main determinants and indicators of fiscal illusion. Most importantly, we find that fiscal illusion negatively affects the shadow economy and the shadow economy positively affects fiscal illusion. Concealing the real tax burden we find that an increase of taxation increases both shadow economic activities and fiscal illusion.
\end{abstract}

JEL-Code: O170, K420, E620.

Keywords: fiscal illusion, shadow economy, MIMIC model, latent variables, tax burden, tax complexity.

Andreas Buehn
University of Cooperative Education
Loebauer Strasse 1
Germany - 02625 Bautzen
buehn@ba-bautzen.de

Andreas Buehn Loebauer Strasse 1 buehn@ba-bautzen.de

\author{
Roberto Dell` Anno* \\ Department of Economics and Statistics \\ University of Salerno \\ Via Giovanni Paolo II, 132 \\ Italy - Fisciano (SA) 84084 \\ rdellanno@unisa.it
}

\author{
Friedrich Schneider \\ Department of Economics \\ Johannes Kepler University of Linz \\ Altenbergerstrasse 69 \\ Austria - 4040 Linz \\ friedrich.schneider@jku.at
}

*corresponding author 


\section{Introduction}

This paper expands previous research on the shadow economy and fiscal illusion. Both, the shadow economy, i.e. the production and distribution of goods and services concealed from the government, and fiscal illusion, i.e. the systematic delusion of key fiscal parameters by taxpayers, are two important - to our opinion - closely linked economic phenomena. On the one hand, the more effective the government can create a fiscal illusion, the more likely it is that voters underestimate the actual or true tax burden of government activities. This potentially affects the size and development of the shadow economy, as the tax burden is often found to be its most important determinant. Hence, the systematic misperception of the true tax burden should reduce people's incentives to work in the shadow economy, as they feel less depleted by public spending. On the other hand, the existence of a large shadow economy potentially incentivizes fiscally illusionary policies. In countries with a large shadow economy, weak institutions and an environment of mistrust towards government policies may make only the instrument of fiscal illusion available to the government to reduce the perceived pressure of taxation and thus the shadow economy. Hence, a sizable shadow economy can go hand in hand with a high level of fiscal illusion.

Although both phenomena are not observable, they leave traces such as the frequency of cash transactions and the complexity of the tax system that can be used to study their relationship. For the first time we analyze the interaction between the shadow economy and fiscal illusion using a multiple indicator multiple causes (MIMIC) model with two latent variables. Selecting appropriate causes and indicator of these two unobservable phenomena we investigate the driving forces behind the shadow economy and fiscal illusion. Differently to previous studies applying a MIMIC model, we do not focus on the measurement of either latent variable. Rather we apply the MIMIC model to explore the mutual interactions between the shadow economy and fiscal illusion. We hypothesize that the better a government is able to "create" a fiscal illusion, the smaller the shadow economy is, all other things being equal. Hence, governments may use fiscal illusion as an additional tool to control shadow economic activities. A second contribution of this paper is to join two strands of the literature, i.e., the literature on fiscal illusion and the literature on the shadow economy.

The paper is organized as follows: Section 2 discusses some theoretical considerations about the potential relationship between fiscal illusion and the shadow economy. In Section 3, we present the empirical analysis studying the shadow economy and fiscal illusion simultaneously in a MIMIC model. Section 4 briefly summarizes the most important findings and concludes.

\section{Fiscal Illusion and the Shadow Economy}

The traditional view on the concept of fiscal illusion is the systematic misperception of key fiscal parameters (taxes) by taxpayers, distorting fiscal choices. ${ }^{1}$ Mill (1848 [1994], p. 237) already discussed the

\footnotetext{
${ }^{1}$ The paper focuses on the relationship between fiscal illusion and the shadow economy and does for this reason discuss the literature only briefly. A comprehensive literature review on fiscal illusion is presented in Dell'Anno and
} 
perception of different taxes: "If all taxes were direct, taxation would be much more perceived than at present, and there would be a security, which now there is not, for economy in the public expenditure." Mill's seminal observation indicates that one important nature of fiscal illusion is political illusion. It occurs when politicians use fiscal instruments to deceive taxpayers making them feel paying less than they are actually contributing to government programs (Fasiani 1941). In this sense, taxpayers potentially attribute more value to public expenditures than they are worth, which in the end leads to a public sector of excessive size (Oates 1988).

To disguise taxes, politicians have several options. Firstly, designing a tax system more complex makes it more difficult for taxpayers to understand its significant elements. As a consequence they very likely underestimate their effective tax burden, allowing the government to increase public expenditures without the full perception of taxpayers (Wagner 1976; Cullis and Jones 1987). Fiscal illusion is also created if governments finance expenditures by debt rather than by tax revenues. According to the Ricardian equivalence theorem people would be indifferent between debt and tax financing if they had rational expectations. ${ }^{2}$ Since they do not, they experience a fiscal illusion or more precisely debt illusion, underestimating future tax liabilities in the form of current public debt. In other words, current taxation generates higher levels of perception of the true burden than public indebtedness. This distortion leads to a systematic underestimation of public expenditures and the cost of government programs. Fiscal illusion is thus the systematic distortion of taxpayer's perceptions by the government.

In contrast, the shadow economy is often defined as all economic activity - and income earned from it that circumvent government regulation, taxation, or observation. Hence, shadow economic activities include unreported income from otherwise official trade in goods and services, i.e., all economic activities that would generally be taxable were they reported to government (tax) authorities are part of the shadow economy. This broad definition of the shadow economy is however difficult to implement empirically. To make it applicable for the empirical analysis presented in section 3, we introduce the following more narrow definition: the shadow economy comprises all market-based, lawful production or trade of goods and services deliberately concealed from public authorities in order to evade either payment of income, value added or other taxes, or social security contributions; to get around certain labor market standards, such as minimum wages, maximum working hours, or safety standards; or to avoid compliance with administrative procedures. This definition does not include illegal economic activities, such as burglary, robbery, or drug dealing.

The discussion of both phenomena in the preceding two paragraphs suggests that fiscal illusion and the shadow economy are interrelated phenomena. Table 1 supports this intuition showing a positive correlation between the two indices of Fiscal illusion available in literature (i.e. Dell'Anno and Mourão 2012; Mourão 2008) and the estimates of the shadow economy obtained by Buehn and Schneider (2012a). The correlations

Mourão (2012) and Cabral and Hoxby (2012). The empirical literature on fiscal illusion is surveyed in Dollery and Worthington (1996). The most recent developments in this literature refers to links between fiscal illusion and behavioural economics (e.g. Congdon et al. 2009, Dell'Anno and De Rosa, 2013) and concept of Tax Salience (e.g. Chetty et al. 2009, Finkelstein 2009). Schneider and Enste (2000) present a comprehensive survey about the shadow economy, also including different measurement methodologies, which we do not discuss here.

${ }^{2}$ However, rational expectations are a necessary but not sufficient condition for Ricardian Equivalence. See Seater (1993) for a survey on this topic. 
are calculated for the 46 countries common to the authors and for comparable periods, i.e. using the averages for the period 2000-2007 on the one hand and the estimates for the year 2006 on the other hand.

Table 1: Correlation Matrix - Fiscal Illusion and the Shadow Economy

\begin{tabular}{c|cccc}
\hline & $\begin{array}{c}\text { Fiscal Illusion } \\
(A v .2000-07)\end{array}$ & $\begin{array}{c}\text { Fiscal Illusion } \\
(2006)\end{array}$ & $\begin{array}{c}\text { Shadow Econ. } \\
(A v .2000-07)\end{array}$ & $\begin{array}{c}\text { Shadow Econ. }{ }^{* * *} \\
(2006)\end{array}$ \\
\hline $\begin{array}{c}\text { Fiscal Illusion } \\
(A v .2000-07)\end{array}$ & 1 & & & \\
\hline $\begin{array}{c}{ }^{* * *} \\
\text { Fiscal Illusion } \\
(2006)\end{array}$ & 0.6256 & 1 & 1 & 1 \\
\hline $\begin{array}{c}\text { Shadow Econ. } \\
(A v .2000-07)\end{array}$ & 0.6948 & 0.7528 & 0.9996 & 1 \\
\hline $\begin{array}{c}\text { Shadow Econ. } \\
(2006)\end{array}$ & 0.6939 & 0.7523 & 0.996 & \\
\hline
\end{tabular}

Notes: * Dell'Anno and Mourão (2012); ${ }^{* *}$ Mourão (2008); ${ }^{* * *}$ Buehn and Schneider (2012a)

On the one hand, an economy with a large shadow sector reduces the quality of institutions and is potentially characterized by low attitudes towards the state. Hence, policymakers are probably keen to apply several strategies limiting the size of the shadow economy. Standard policy instruments often recommended by economist are - in addition to tax reforms reducing the tax and regulatory burden - to increase the effectiveness of tax auditing, the enforcement of tax rules and regulations, or the punishment of shadow workers or tax evaders. An alternative way for politicians to deplete the shadow economy may is to systematically distort the true tax burden of citizens. Assuming that policymakers explore all available policy options, a higher shadow economy can potentially be an incentive for policymakers to adopt strategies to hide the true tax burden to taxpayers. In this way they can avoid a further increase or even induce a reduction of tax evasion and the shadow economy. Hence, a higher shadow economy may lead to a higher level of fiscal illusion, all other things being equal.

If governments successfully create the illusion of a lower tax burden, individuals do have fewer incentives to escape into the shadow economy or to evade taxes. As a consequence, the shadow economy should be smaller in the presence of a high level of fiscal illusion. Alternatively, however, it might be possible that the existence of the shadow economy is just an indication of the government's failure to create a fiscal illusion. Because citizens correctly perceive their true tax burden, they realize contributing too much to government programs. By escaping into the shadow economy or evading taxes, they can reduce their effective tax burden to a level that matches the value they attribute to public expenditures programs. The next section presents a structural equation model, which allows us to empirically investigate this mutual relationship between fiscal illusion and the shadow economy. 


\section{The Empirical Analysis}

\subsection{The SEM and MIMIC approaches}

Structural Equation Models (SEM) are based on statistical relationships among latent (i.e. unobservable) and manifest (i.e. observable) variables to simultaneously estimate relationships between multiple independent, dependent and latent variables. Combining factor analysis and the multivariate regression model, SEM integrate two important aspects of economic analysis: (1) variable measurability and observability and (2) the identification of their causal relationships. In this paper, a special type of a SEM is employed, i.e., a MIMIC model with two latent variables, to study the nexus between fiscal illusion and the shadow economy. ${ }^{3}$

A MIMIC model has two parts: a measurement model and a structural model. The measurement model specifies the relationships between latent variables (shadow economy and fiscal illusion) and their indicators. Usually the latent variables $\left(f_{l}\right.$ and $\left.f_{2}\right)$ determine linearly, subject to disturbances , a set of six endogenous indicators $(y)$. In this paper we propose an extended version of measurement model that includes among the determinants of indicators also observed exogenous causes $(x)$. Following this specification we aim to solve a relevant issue in the use of MIMIC specification to economics application, i.e. the omission of some direct effects of causes on indicators. That is, each of two latent variables has three observable indicators and each indicators has observed exogenous and unobserved endogenous determinants. The covariance matrix of the measurement errors, , is given by the matrix $\Theta^{\varepsilon} .^{4}$ In matrix notation, the specification of measurement model for the widest specification (MIMIC 8-2-6)is given by:

$$
\left[\begin{array}{l}
y_{1} \\
y_{2} \\
y_{3} \\
y_{4} \\
y_{5} \\
y_{6}
\end{array}\right]=\left[\begin{array}{llllll}
\lambda_{11} & \lambda_{12} & \lambda_{13} & 0 & 0 & 0 \\
0 & 0 & 0 & \lambda_{24} & \lambda_{25} & \lambda_{26}
\end{array}\right]\left[\begin{array}{l}
f_{1} \\
f_{2}
\end{array}\right]+\left[\begin{array}{cccccc}
0 & 0 & \alpha_{13} & 0 & 0 & 0 \\
0 & 0 & \alpha_{23} & 0 & 0 & 0 \\
0 & 0 & 0 & 0 & 0 & 0 \\
0 & 0 & 0 & 0 & 0 & 0 \\
\alpha_{51} & \alpha_{52} & 0 & 0 & \alpha_{55} & 0 \\
0 & 0 & 0 & 0 & 0 & 0 \\
0 & 0 & 0 & 0 & \alpha_{75} & 0 \\
0 & 0 & 0 & 0 & 0 & 0
\end{array}\right]\left[\begin{array}{c}
x_{1} \\
x_{2} \\
x_{3} \\
x_{4} \\
x_{5} \\
x_{6} \\
x_{7} \\
x_{8}
\end{array}\right]+\left[\begin{array}{c}
\varepsilon_{1} \\
\varepsilon_{2} \\
\varepsilon_{3} \\
\varepsilon_{4} \\
\varepsilon_{5} \\
\varepsilon_{6}
\end{array}\right]
$$

The structural equation model linearly determines the latent variables $f_{l}$ and $f_{2}$ by a set of eight exogenous causes. Because the structural equation model only partially explains the latent variables, the structural disturbance error terms ${ }_{1}$ and ${ }_{2}$ represent the unexplained components. We assume B to be a $(2 \times 8)$ matrix of structural coefficients describing the "causal" relationships between the latent variables $f_{l}$ and $f_{2}$ and their causes. In matrix notation, MIMIC 8-2-6 specification it is given as:

\footnotetext{
${ }^{3}$ Structural equations models with two latent variables are rarely applied in the economic literature. Important exceptions are Dreher et al. (2009) as well as Buehn and Schneider (2012b).

${ }^{4}$ In the standard MIMIC model (Jöreskog and Goldberger 1975), the measurement errors are assumed to be independent of each other, but this restriction can be relaxed (Stapleton 1978). In this paper, several covariances between indicators are relaxed since they are empirically and theoretically plausible.
} 


$$
\left[\begin{array}{l}
f_{1} \\
f_{2}
\end{array}\right]=\left[\begin{array}{cc}
0 & \eta_{12} \\
\eta_{21} & 0
\end{array}\right]\left[\begin{array}{l}
f_{1} \\
f_{2}
\end{array}\right]+\left[\begin{array}{llllllll}
\beta_{11} & \beta_{12} & \beta_{13} & \beta_{14} & \beta_{15} & \beta_{16} & 0 & 0 \\
0 & 0 & 0 & 0 & \beta_{25} & \beta_{26} & \beta_{27} & \beta_{28}
\end{array}\right]\left[\begin{array}{l}
x_{1} \\
x_{2} \\
x_{3} \\
x_{4} \\
x_{5} \\
x_{6} \\
x_{7} \\
x_{8}
\end{array}\right]+\left[\begin{array}{l}
\zeta_{1} \\
\zeta_{2}
\end{array}\right]
$$

Without loss of generality, the variances of the structural disturbance error terms $\quad{ }_{1}$ and $\quad{ }_{2}$ are abbreviated by a non-diagonal matrix . The MIMIC model assumes that $E(\zeta)=E(\varepsilon)=0$; the error terms do not correlate with the causes $[E(x \zeta)=0]$; the error terms in the measurement model do not correlate either with the causes $\left[E\left(x \varepsilon^{\prime}\right)=0\right]$ or with the latent variables $\left[E\left(f \varepsilon^{\prime}\right)=0\right]$; and, finally, the measurement errors do not correlate with structural disturbances $[E(\varepsilon \zeta)=0]$.

Assuming multivariate normality, the standard approach is to apply maximum-likelihood (ML) method to estimate the parameters by minimizing the discrepancy between the covariance matrix of the observable variables, computed directly from the sample, and the covariance matrix implied by the model. However, in our dataset multivariate normality does not hold, variables include missing values and we encounter convergence problems by using ML estimators. ${ }^{5}$ Accordingly, the asymptotic distribution free method (ADF - or WLS, Weighted Least Squares, which is used in the LISREL language - proposed by Browne 1984) is applied. ADF is considered a better option because it makes no assumption of joint normality and can be used even when errors are heteroskedastic. However, Olsson et al. (2000) suggest caution to use this method because it performs worse than ML estimator by tending to give unreliable estimates and over-optimistic values of fit for wrongly specified models and small sample size.

The necessary condition for identification is that the number of structural parameters should be equal to the number of reduced-form parameters. An observation of the reduced-form parameters shows that unique solutions to the measurement and structural parameters and cannot be obtained from the reduced-form model. This occurs because altering the scale of either $f_{1}$ and $f_{2}$ yields an infinite number of solutions for and from the same reduced-form solution. The inability to obtain unique solutions for and causes an identification problem that can be solved by (i) constraining one of the paths from the latent variable to one of its indicator variables, or by (ii) fixing the variances of the structural disturbance error terms, $\psi_{11}$ and $\psi_{22}$ to 1 . In this paper we consider the latter alternative to identify the model more

\footnotetext{
${ }^{5}$ Monte Carlo studies demonstrate (see e.g. Anderson and Gerbing 1984; Boomsma 1982, 1985) that problems of non-positive definite matrices arise frequently when data provides relatively little information such as few observable indicator variables, small factor loadings or a high number of missing values (Bollen and Long 1993).
} 
appropriate as we do not aim to use the MIMIC model estimates to assess the size of the unobservable variables. ${ }^{6}$

\subsection{Observable structural causes and indicators of both latent variables}

An extensive literature exists on the empirical analysis of the shadow economy (e.g., Schneider 2005, Buehn and Schneider 2012a) and fiscal illusion (e.g, Mourão 2008, Dell'Anno and Mourão 2012, Dell'Anno and Dollery 2014). These works are used as guidance for the selection of the causes and indicator variables of the MIMIC model. The previous section has made clear that the rationale behind the selection of the observable variables is key for the MIMIC approach. Duncan (1975) points out that the meaning of the latent variables, and hence the reliability of the estimates, depends on how comprehensively the causal and indicator variables correspond to the intended content of the latent variables. To define the latent variable shadow economy as precise as possible, six potential causes and three indicators are chosen. Given data availability, the structural model investigates the relationships between the shadow economy $\left(f_{1}\right)$ and the following variables ${ }^{7}$ :

$\mathbf{X}_{\mathbf{1}}$, Personal income tax: The higher (lower) the individual income tax burden, the larger (smaller) the shadow economy, ceteris paribus; i.e., $\beta_{11}>0$.

$\mathbf{X}_{2}$, Corporate income tax: The higher (lower) the corporate income tax rate, the larger (smaller) the shadow economy, ceteris paribus; i.e., $\beta_{12}>0$.

$\mathbf{X}_{3}$, Unemployment rate: the higher (lower) the unemployment rate, the more (less) time and incentives people have to work underground and hence the bigger (smaller) is the shadow economy, ceteris paribus; i.e., $\beta_{13}>0$.

However, Tanzi (1999) as well as Buehn and Schneider (2012a) argue that the effect of unemployment on the shadow economy is ambiguous, i.e., both a positive and negative sign may be observed in an empirical analysis. Buehn and Schneider's line of reasoning is as follows: income losses due to unemployment may reduce demand in both the shadow and official economies (income effect). At the same time, substitution of official demand for goods and services for unofficial demand may take place as unemployed workers turn to the shadow economy - where cheaper goods and services make it easier to countervail utility losses (substitution effect). This behavior may stimulate additional demand in the shadow economy. If the income effect exceeds the substitution effect, a negative relationship develops. Likewise, if the substitution effect exceeds the income effect, the relationship is positive. Moreover, the ambiguous effect of unemployment on the shadow economy may not only be due to the countervailing forces of the income and substitution effect but a consequence of a supply side effect when the unemployed search for and take up jobs in the shadow economy. While the shadow economy in this case clearly increases, the behavior of the

\footnotetext{
${ }^{6}$ The first alternative is superior when the model is used to estimate the size of latent variables as it anchors the meaning of latent variable to the dimension of the reference indicator. See Dell'Anno (2007) for details.

${ }^{7}$ There is an intensive discussion, why the variables $\mathrm{X}_{1}, \mathrm{X}_{2}, \mathrm{X}_{4}$ and $\mathrm{X}_{5}$ are key factors or driving forces for shadow economy activities. Compare for example Schneider and Enste (2000), Schneider (2005) and Feld and Schneider (2010).
} 
unemployment rate depends on whether informal worker are considered unemployed in the official statistics or not. In the case informal workers are considered unemployed and part of the official unemployment statistics, the unemployment rate does not change. However, if informal workers are not considered unemployed, unemployment decreases and one would observe a negative relationship between the shadow economy and unemployment. Hence, the relationship between unemployment and the shadow economy is less clear and is - as explained above - theoretically ambiguous.

$\mathbf{X}_{4}$, Business freedom: A fourth important determinant may affecting the size of the shadow economy is the burden of regulation for business activities. To take the extent of business regulations into account, we employ the index of business freedom, as estimated by the Heritage Foundation. It seems reasonable to assume that the greater the business freedom (i.e. the higher the index score), the lower the size of the shadow economy. According to this view, we expect the estimated coefficient to be negative, i.e., $\beta_{14}<0$.

$\mathbf{X}_{5}$, Tax burden: Tax revenues as percentage of GDP are used as measure of the overall tax burden in an economy, which potentially influences both, the extent of fiscal illusion and the size of the shadow economy. The higher the tax burden, the stronger is the incentives for individuals to operate in the shadow economy and for the government to delude the true burden through fiscal illusion. We thus use the overall tax burden as potential cause for both the shadow economy and fiscal illusion and expect a higher (lower) overall tax burden to provoke more (less) shadow economic activities, ceteris paribus, i.e., $\beta_{15}>0$.

For fiscal illusion, four main structural causes, enhancing the efficacy of fiscal illusion, and three main categories of policies, capable of distorting taxpayers' perceptions of their true tax burden, are selected. As argued above, we believe that the tax burden can be seen as a proxy for policymakers' needs to reduce the perception of tax pressure. A higher (effective) tax burden encourages the government to adopt tax policies aimed at increasing fiscal illusion. Thus, the expected correlation between the overall tax burden and fiscal illusion is positive, i.e., $\beta_{25}>0$. Further important determinants of fiscal illusion are:

$\mathbf{X}_{6}$, Self-employment: This variable is considered as potential cause for both fiscal illusion and the shadow economy. The shadow economy literature presents unambiguous evidence that self-employed have much more possibilities to work in the shadow economy, hence the higher the self-employment ratio is, the larger the shadow economy should be, ceteris paribus, i.e. $\beta_{16}>0 .^{8}$

Concerning fiscal illusion, a higher ratio of self-employed to the totally employed population can increase the policymaker's needs to conceal the tax burden. Fasiani (1941) already argued that a higher selfemployment ratio requires a higher degree or more "active" tax compliance as the system of withholding income tax is rather partial for self-employed. Hence, we expect a higher self-employment ratio to increase the level of fiscal illusion because it incentivizes policymakers to distort the perception of the tax burden, i.e. $\beta_{26}>0$.

${ }^{8}$ Compare e.g. the survey of Feld and Schneider (2010) and the references mentioned there. 
$\mathbf{X}_{7}$, Top income tax rate: We assume that a higher (statutory) top income tax rate encourages a government to adopt tax policies aimed at creating a fiscal illusion. ${ }^{9}$ A highly visible statutory top income tax rate very likely produces perceptions of a burdensome tax regime, which result in high electoral cost for the government. Buchanan (1967, p. 140) states that "the institution of progression, per se, tends to create an excess feeling of tax burden for the taxpayer. The effect here comes from the divergence between the average and the marginal rate of tax, and the observed tendency of persons to think in terms of marginal rates." Thus, the expected correlation between the top (statutory) income tax rate and fiscal illusion is negative because governments that use high top tax rates make taxes much more visible. This suggests that those governments are more transparent towards citizens with respect to the structure of the tax system, in particular with respect to tax rates, which could also be an indication of less fiscal illusion policies present in a society. We thus hypothesize a negative correlation between the top income tax rate and fiscal illusion, i.e. $\beta_{27}<0$.

$\mathbf{X}_{\mathbf{8}}$, Secondary school enrolment: The fourth potential cause of fiscal illusion takes into account the ability of a society to correctly evaluate the beneficiaries of both tax reforms and public expenditure programs. Assuming that this ability depends on the average level of education, we take into account the secondary school enrolment rate, i.e. the ratio of children enrolled in secondary education to the population of official secondary education age. A more educated society should make it more difficult for policymakers to effectively implement fiscal illusion policies to distort taxpayers' perceptions. Thus, the government has to implement more strategies and increase the level of fiscal illusion to bias the taxpayers' perceptions about the true tax burden. Hence, we expect a positive correlation between the secondary school enrolment rate and the level of fiscal illusion, i.e. $\beta_{28}>0$.

The measurement model includes three variables that are typically used in the literature as indicators of the shadow economy. In addition, three variables, representing the most common strategies to reduce citizens' perceptions of the true tax burdens, are employed as indicators of fiscal illusion. In particular, the measurement model links the following six indicators to the unobservable variables: ${ }^{10}$

$\mathbf{Y}_{1}$, Labor force participation: A low (high) labor force participation rate in the official economy may be seen as indication of prevalent (rare) shadow economic activities, ceteris paribus. We thus expect $\lambda_{11}<0$.

$\mathbf{Y}_{2}$, Growth rate of real GDP: The theoretical literature does not offer unambiguous guidance concerning the effects of the shadow economy on official economy and vice versa. ${ }^{11}$ For instance, Kaufmann and Kaliberda (1996) show that countries experiencing a decline in official GDP were able to mitigate the

\footnotetext{
${ }^{9}$ We assume that the top marginal tax rate does not affect the size of the shadow economy directly but only through fiscal illusion. This hypothesis is motivated by the intuition that only a minority of taxpayers (i.e. those with the highest income) are actually subject to this tax rate. In this sense, the top statutory tax rate mainly affects the taxpayers' perceptions of the tax burden. That is, although the two measures are related $\left(\sigma_{57} \neq 0\right)$ the top statutory tax rate has a direct effect on fiscal illusion only.

${ }^{10}$ There is a vast literature on possible indicators of the shadow economy. Compare e.g. Schneider and Enste (2000), Feld and Schneider (2010), and Schneider et al. (2010).

${ }^{11}$ For an overview see Dell'Anno (2008).
} 
consequences through growth of the shadow economy. On the contrary, Chong and Gradstein (2007) find a positive - potentially demand-side driven - relationship between the shadow economy and official growth. Following the slight prevalence of a positive correlation found in the empirical literature, we expect that the higher the official growth rate of real GDP is, the larger the shadow economy, ceteris paribus, i.e., $\lambda_{12}>0$.

$\mathbf{Y}_{3}$, Currency ratio: It is commonly assumed that cash is used to pay for goods and services produced in the shadow economy as it leaves no trace compared to bank transfers or other tractable payment methods. We thus expect a positive sign for the coefficient of the currency ratio, ceteris paribus, i.e., $\lambda_{13}>0$.

$\mathbf{Y}_{4}$, Public debt: A common strategy to create fiscal illusion is to increase public debt. The motivation behind this argument is that taxpayers are more likely to perceive the cost of public programs if they pay for them through current taxation than if tax liabilities are deferred through public-sector borrowing (Oates 1988). Hence, we expect a positive correlation between fiscal illusion and public debt, ceteris paribus, i.e., $\lambda_{24}>0$.

$\mathbf{Y}_{5}$, Share of indirect taxation: The second variable included as indicator of fiscal illusion is the share of indirect taxation. According to the "Mill hypothesis", fiscal extraction through indirect taxation is underestimated compared to direct taxation because it is less visible to taxpayers. The "Mill' hypothesis" stressed by Schmölders (1960) and Buchanan (1967), represents one of the most common forms policymakers use to reduce the perceived sacrifice of taxpayers. More recently, Sausgruber and Tyran (2005) show that indirect taxes exhibit a different incidence than direct taxes because indirect taxes are less visible. In this sense, a positive coefficient is expected for the share of indirect taxation, ceteris paribus, i.e., $\lambda_{25}>0$.

$\mathbf{Y}_{6}$, Tax complexity: Finally, we use the complexity of the tax system as indicator of fiscal illusion. The more complex and complicated a tax and revenue system, the more likely it is that taxpayers underestimate the tax burden and misperceive the true tax liabilities, all other things being equal. Following Wagner (1976), we compute the Herfindahl index (H) of a country's revenue system. ${ }^{12}$ A higher value of this index means a less complex revenue system; the revenue-complexity hypothesis thus posits a negative coefficient for the Herfindahl index of tax complexity, i.e., $\lambda_{26}<0$.

Figure 1 shows the path diagram of the widest MIMIC model specification, including eight causes, two latent variables and six indicators. It has been estimated for an unbalanced panel of a cross-section of 104 countries over the period 1989 to 2009 (21 years). The list of countries included in the sample as well as the definitions and data sources are provided in Appendix. As common, the observable variables in Figure 1 are represented by rectangles and the latent variables by ovals. An arrow represents the effect of one variable on the other and the parameters represent the coefficients to be estimated.

To make the SEM approach suitable to the data set's panel structure, we transform the observable variables into deviations from the country mean over the sample period. Accordingly, the variables now

\footnotetext{
${ }^{12}$ We follow the literature and use different types of taxation to compute the Herfindahl index. See Appendix for details.
} 
have the same mean (zero) across countries. The deviations from the country mean are computed as follows:

$$
x_{j i t}=\left(x_{j i t}^{r}-\sum_{t} x_{j i} / N\right) ; y_{j i t}=\left(y_{j i t}^{r}-\sum_{t} y_{j i} / N\right) \text {, }
$$

where superscript $r$ denotes raw data; $\mathrm{j}=1,2, \ldots, 14$ indicates the observable causes and indicators variables; $i=1,2, \ldots, 104$ denotes the number of countries; $t=1989, \ldots, 2009$ specifies the observation period; and $\mathrm{N}$ is the number of non-missing observations for each country. This approach makes it feasible to consider heterogeneity across cross-sectional units in the MIMIC model and is motivated by the relevance of country fixed effects in the model.

Figure 1: Path Diagram MIMIC 8-2-6

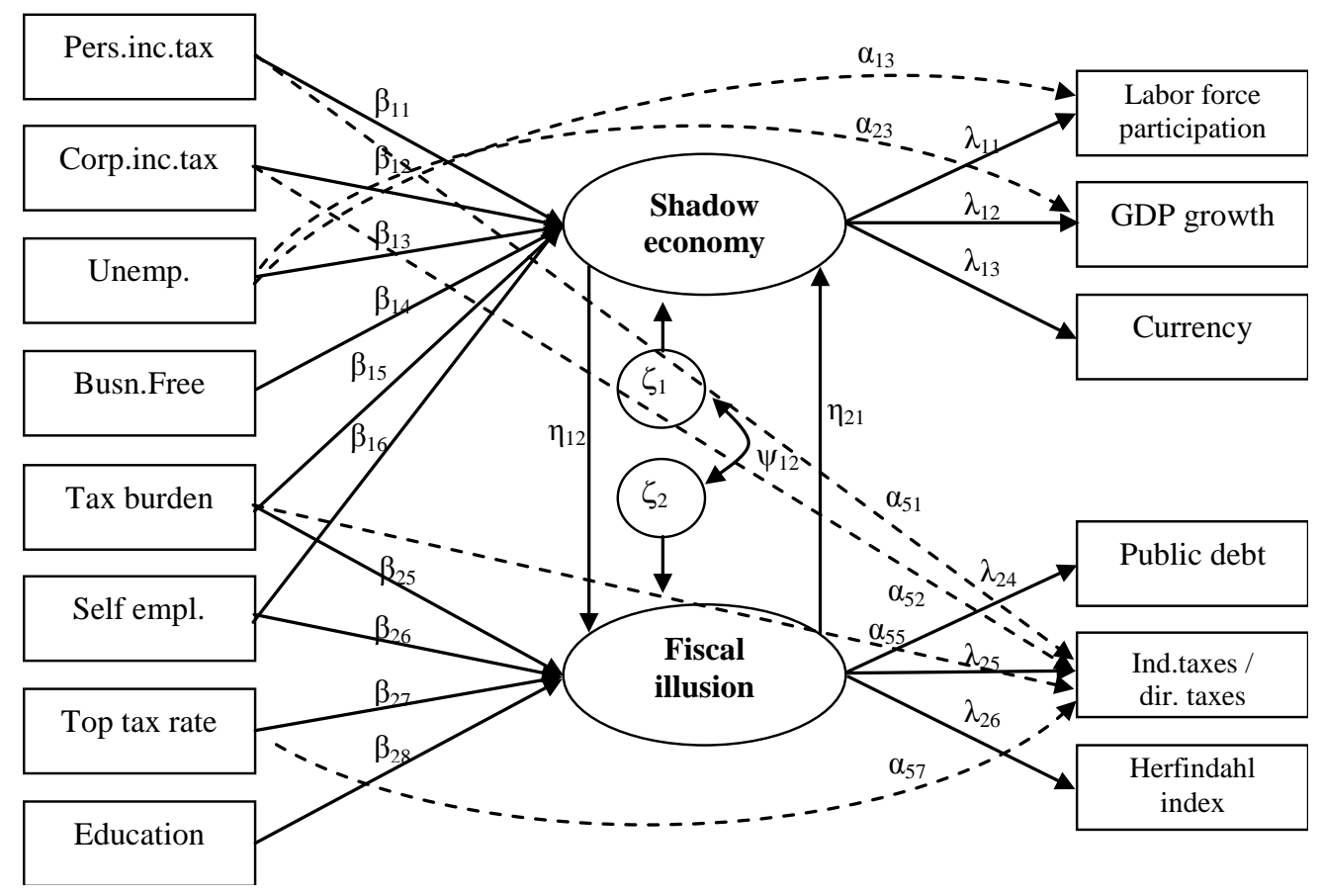

Table 2 shows the results of three MIMIC model specifications: MIMIC 8-2-6 (eight causes - two latent variables - six indicators); MIMIC 7-2-6 and MIMIC 8-2-5. 
Table 2: MIMIC models and parameter estimates

\begin{tabular}{|c|c|c|c|c|c|c|c|}
\hline & & \multicolumn{2}{|c|}{ MIMIC1 8-2-6 } & \multicolumn{2}{|c|}{ MIMIC 7-2-6 } & \multicolumn{2}{|c|}{ MIMIC 8-2-5 } \\
\hline \multicolumn{2}{|l|}{ Causes } & SE & FI & SE & FI & SE & FI \\
\hline Personal income tax & $\beta_{11}$ & $\begin{array}{l}-0.59 \\
(-1.50)\end{array}$ & - & - & - & $\begin{array}{l}-0.25 \\
(-1.11)\end{array}$ & - \\
\hline Corporate income tax & $\beta_{12}$ & $\begin{array}{l}-3.52^{* * *} \\
(-3.37)\end{array}$ & - & $\begin{array}{l}-4.78^{* * *} \\
(-2.45)\end{array}$ & - & $\begin{array}{l}-1.95^{\text {*3*k }} \\
(-3.30)\end{array}$ & - \\
\hline Unemployment rate & $\beta_{13}$ & $\begin{array}{l}0.44^{* *} \\
(2.00)\end{array}$ & - & $\begin{array}{c}0.63 \\
(1.53)\end{array}$ & - & $\begin{array}{l}0.24^{* *} \\
(2.14)\end{array}$ & - \\
\hline Business Freedom index & $\beta_{14}$ & $\begin{array}{l}-0.43^{* * * *} \\
(-3.40)\end{array}$ & - & $\begin{array}{l}-0.61 \\
(-2.41)\end{array}$ & - & $\begin{array}{l}-0.38^{* * * *} \\
(-3.59)\end{array}$ & - \\
\hline Tax burden & $\beta_{15} ; \beta_{25}$ & $\begin{array}{l}1.17^{* * * * *} \\
(2.69)\end{array}$ & $\begin{array}{c}0.09 \\
(0.77)\end{array}$ & $\begin{array}{l}1.58^{* * *} \\
(2.19)\end{array}$ & $\begin{array}{c}0.19 \\
(1.00)\end{array}$ & $\begin{array}{l}0.69^{* * * * *} \\
(2.69)\end{array}$ & $\begin{array}{c}0.11 \\
(1.45)\end{array}$ \\
\hline Self-employment rate & $\beta_{16} ; \beta_{26}$ & $\begin{array}{c}0.01 \\
(0.13) \\
\end{array}$ & $\begin{array}{c}-0.00 \\
(-0.05)\end{array}$ & $\begin{array}{c}-0.05 \\
(-0.27) \\
\end{array}$ & - & $\begin{array}{c}0.10 \\
(1.33) \\
\end{array}$ & $\begin{array}{c}0.01 \\
(0.44) \\
\end{array}$ \\
\hline Top income tax rate & $\beta_{27}$ & - & $\begin{array}{l}-0.48^{* * * *} \\
(-2.64)\end{array}$ & - & $\begin{array}{l}-0.79^{* * *} \\
(-1.98)\end{array}$ & - & $\begin{array}{l}-0.08^{*} \\
(-1.69)\end{array}$ \\
\hline Secondary education & $\beta_{28}$ & - & $\begin{array}{l}0.08^{* * *} \\
(3.37)\end{array}$ & - & $\begin{array}{l}0.10^{* *} \\
(2.39)\end{array}$ & - & $\begin{array}{l}0.05^{\text {**** }} \\
(3.14) \\
\end{array}$ \\
\hline \multicolumn{8}{|l|}{ Indicators } \\
\hline Labor force participation & $\lambda_{11}$ & $\begin{array}{l}0.08^{* * * *} \\
(3.41)\end{array}$ & - & $\begin{array}{l}0.05^{* * *} \\
(2.72)\end{array}$ & - & $\begin{array}{l}0.08^{* *} \\
(2.06) \\
\end{array}$ & - \\
\hline $\begin{array}{c}\text { Growth rate } \\
\text { of real GDP per capita }\end{array}$ & $\lambda_{12}$ & $\begin{array}{l}0.03^{* *} \\
(2.00)\end{array}$ & - & $\begin{array}{l}0.03^{* * *} \\
(2.08)\end{array}$ & - & - & - \\
\hline Currency ratio & $\lambda_{13}$ & $\begin{array}{l}0.99^{* 3 * *} \\
(3.09)\end{array}$ & - & $\begin{array}{l}0.63^{* * * *} \\
(2.46) \\
\end{array}$ & - & $\begin{array}{l}1.42^{* * * *} \\
(3.03)\end{array}$ & - \\
\hline $\begin{array}{c}\text { Public debt } \\
\text { in \% of GDP }\end{array}$ & $\lambda_{24}$ & - & $\begin{array}{l}3.71^{* * * *} \\
(3.41) \\
\end{array}$ & - & $\begin{array}{l}2.56^{* *} \\
(2.52)\end{array}$ & - & $\begin{array}{l}5.67^{* * *} \\
(3.06) \\
\end{array}$ \\
\hline $\begin{array}{c}\text { Indirect taxes/ } \\
\text { direct taxes }\end{array}$ & $\lambda_{25}$ & - & $\begin{array}{l}0.10^{* * *} \\
(2.34)\end{array}$ & - & $\begin{array}{c}0.07^{*} \\
(1.93) \\
\end{array}$ & - & $\begin{array}{l}0.17^{\text {*** }} \\
(2.29)\end{array}$ \\
\hline $\begin{array}{c}\text { Herfindahl index } \\
\text { of tax revenue }\end{array}$ & $\lambda_{26}$ & - & $\begin{array}{c}-0.00 \\
(-1.19) \\
\end{array}$ & - & $\begin{array}{c}-0.00 \\
(-1.49) \\
\end{array}$ & - & $\begin{array}{c}-0.00 \\
(-1.17) \\
\end{array}$ \\
\hline \multicolumn{8}{|l|}{ Interactions terms } \\
\hline $\begin{array}{l}\text { Shadow ec. } \rightarrow \\
\text { fiscal illusion } \\
\end{array}$ & $\eta_{12}$ & $\begin{array}{r}0.4 \\
(5 \\
\end{array}$ & & & & & \\
\hline Fiscal illusion $\rightarrow$ shadow ec. & $\eta_{21}$ & $\begin{array}{l}-2 . \\
(-5 \\
\end{array}$ & & & & $\begin{array}{l}-2 \\
(- \\
\end{array}$ & \\
\hline \multicolumn{8}{|c|}{ Controls: Causes $\rightarrow$ Indicators } \\
\hline $\begin{array}{l}\text { Unemployment } \rightarrow \\
\text { Labor force part. }\end{array}$ & $\alpha_{13}$ & & & & & & \\
\hline $\begin{array}{c}\text { Unemployment } \rightarrow \\
\text { Growth rate real GDP cap }\end{array}$ & $\alpha_{23}$ & $\begin{array}{l}0.3 \\
(2 \\
\end{array}$ & & & & & \\
\hline $\begin{array}{c}\text { Personal income tax } \rightarrow \\
\text { Indirect taxes/direct taxes }\end{array}$ & $\alpha_{51}$ & $\begin{array}{l}-0 . \\
(-4 \\
\end{array}$ & & & & $\begin{array}{l}-0 \\
(- \\
\end{array}$ & \\
\hline $\begin{array}{l}\text { Corporate income tax } \rightarrow \\
\text { Indirect taxes/direct taxes }\end{array}$ & $\alpha_{52}$ & & & & & & \\
\hline $\begin{array}{c}\text { Tax burden } \rightarrow \\
\text { Indirect taxes/direct taxes }\end{array}$ & $\alpha_{55}$ & & & & & & \\
\hline $\begin{array}{c}\text { Top income tax rate } \rightarrow \\
\text { Indirect taxes/direct taxes }\end{array}$ & $\alpha_{57}$ & & & & & & \\
\hline $\begin{array}{c}\text { Covariance between } \\
\text { Errors of latent variables }\end{array}$ & $\psi_{12}$ & $\begin{array}{r}-15 \\
(-2\end{array}$ & & $\begin{array}{r}-25 \\
(-1\end{array}$ & & & \\
\hline \multicolumn{8}{|c|}{ Goodness-of-fit statistics } \\
\hline$\chi^{2}(p-v a l u e)$ & & 87.39 & $0.00)$ & 78.60 & $.00)$ & 65.8 & $.00)$ \\
\hline Degrees of freedom (observa & ions) & 44 & & 40 & & & \\
\hline RMSEA & & & & & & & \\
\hline Test of close fit (p-value RM & $E A<0.05)$ & & & & & & \\
\hline
\end{tabular}

Notes: t-statistics are given in parentheses. ${ }^{*} \mathrm{p}<.1 ;{ }^{* *} \mathrm{p}<.05 ;{ }^{* * *} \mathrm{p}<.01$. Intercepts are omitted. The models have been estimated for an unbalanced panel of a cross-section of 104 countries over the period 1989 to 2009 (21 years). 
Several criteria can be used to assess the fit of SEM models. The chi-square $\left(\chi^{2}\right)$ distribution for the goodness of fit is the classical test to evaluate differences between the observable data and the model prediction. A small $\chi^{2}$ is typically a sign of a good model fit and the higher the probability level (p-value) associated with chi square, the better the fit. This test is however highly sensitive to departures from multivariate normality and sample size. Due to this drawback of the $\chi^{2}$-test, alternative fit statistics have been developed. One of the most frequently used statistics is the Root Mean Square Error of Approximation (RMSEA) proposed by Steiger and Lind (1980). The RMSEA incorporates a penalty function for poor model parsimony and thus becomes sensitive to the number of parameters estimated and relatively insensitive to the sample size (Brown 2006). The RMSEA values are classified into four categories: close fit $(.00-.05)$, fair fit $(.05-.08)$, mediocre fit (.08-.10), and poor fit (over .10). The RMSEA p-values of all three models estimated and shown in Table 2 reveal a good fit. Finally, as we estimate a nonrecursive model (i.e. there is a feedback loop between latent variables), we check stability condition for simultaneous equation system by calculating the eigenvalue stability condition (see Bollen, 1989). We find that all eigenvalues of MIMIC 8-2-6 and MIMIC 7-2-5 have a module lower than one. Hence we consider these models to be stable. Given that the model MIMIC 8-2-6 has the best goodness of fit statistics, and taking into account that our results are robust to alternative model specifications, we consider this specification as the most reliable model.

The estimated coefficients between fiscal illusion and the shadow economy are both statistically significant. In particular while the coefficient for the effect of the shadow economy on fiscal illusion is positive the simultaneous effect of fiscal illusion on the shadow economy is negative. That is, if fiscal illusion increases the shadow economy reduces, all other things being equal, while a variation in the size of the shadow economy has a positive feedback effect on fiscal illusion. That is, the larger the shadow economy, the more fiscal illusion the government needs to create in order to distort the taxpayers perceptions about the true tax burden.

The results of the MIMIC model concerning the shadow economy show that the overall tax burden has the expected positive sign indicating that a higher total tax burden may result in more economic activities taking place in the shadow economy. Also, less freedom for businesses - i.e. the estimator is as hypothesized negatively correlated to the shadow economy - increases the shadow economy. The unemployment rate is as expected positively correlated to the shadow economy (MMIC 8-2-6 and MIMIC 8-2-5). The higher the unemployment rate, the more labor is supplied in the shadow economy, all other things being equal. People simply try to earn additional income in the shadow economy to compensate income and hence utility losses due to unemployment. Accordingly, we do find support for the predominant hypothesis that a higher unemployment rate in an economy may results in larger shadow economies. Concerning the correlation between the corporate income tax and the shadow economy we get a negative coefficient, which does not match with our hypothesis. A potential explanation for this somewhat surprising finding might be given taking into account the negative correlation between fiscal illusion and the shadow economy. The higher the level of fiscal illusion a government imposes, the lower the shadow economy, all other things being equal, because taxpayers underestimate the true tax burden and do less often engage into shadow economic compared to a higher perceived tax burden. The government 
can thus impose higher corporate tax rates without increasing the shadow economy; if the level of fiscal illusion is high enough shadow economic activities may reduce although the government increases the corporate tax rate.. The remaining causes, i.e. the personal income tax rate and the self-employment rate are not statistically different from zero.

Concerning the indicators of the shadow economy, we find that the shadow economy in all specifications positively correlated to the growth rate of real GDP per capita and the currency ratio. Both findings are in line with our expectations and the literature. The correlation of the labor force participation rate and the shadow economy is however always positive. Changes in the participation rate reflect a flow of resources into and out of the official economy. Whether these changes are due to the shadow economy is debatable and no consensus exists in the literature as to whether a decreasing shadow economy is indicated by higher labor force participation rates. For example, over the last thirty years, the composition of the labor force has changed considerably and changes in the labor force participation may be caused by other reasons, e.g. by a growing female participation in the workforce, than by changes of the shadow economy. Moreover, if economic agents are faced with a burdensome tax system and try to reduce the tax burden through shadow economic activities, the correlation may be positive. A growing economy produces more jobs in the formal sector but at the same time more opportunities in the shadow economy as total demand in the economy increases. Maximizing their (net) income, agents would increase their activities in the shadow economy and a positive correlation would be observed.

Looking at the estimated coefficients of the causes for fiscal illusion we find, as expected, the tax burden to have a positive coefficient. However, it is not statistically significant. The self-employment rate is also not statistically significant. The top income tax rate and the secondary school enrolment rate (education) have the expected negative and positive correlations to fiscal illusion, respectively. These results confirm our theoretical considerations that higher top income tax rate may be an indication of more transparent and less illusive government policies. The more educated citizens are on average however, the more illusive strategies and fiscal illusion policies governments need to adapt if they wish to delude the taxpayers' true tax burden. Concerning the indicators of fiscal illusion, central government debt as percentage of GDP and the ratio of indirect taxes to direct taxes show the expected positive signs in all MIMIC model specification. The Herfindahl index of tax system complexity has however no statistically significant correlation to fiscal illusion.

Finally, we turn to interpret the coefficients indicating the influence from the shadow economy to fiscal illusion and vice versa. While the coefficient describing the influence of the shadow economy on fiscal illusion is positive, the coefficient describing the influence of fiscal illusion on the shadow economy is negative. When interpreting the negative link between fiscal illusion and the shadow economy one should take into account the fact that an increasing tax burden contributes to more shadow economic activities and - at the same time - encourages the government to implement a tax policy aimed to increase fiscal illusion. Thus, the rationale behind the result of a higher level of fiscal illusion decreasing the shadow economy potentially is that policymakers aim to reduce the incentives for tax evasion through fiscal illusion mainly in countries with a large shadow economy. One measure policymakers may use, which is 
empirically supported by our model, is to systematically delude taxpayers (i.e., from Table 3, the total effect of an increase of fiscal illusion is to reduce shadow economy of -1.21).

For the link from the shadow economy to fiscal illusion, we find a positive effect; an increase of shadow economic activities increases fiscal illusion, all other things being equal. The rationale for this finding may be that a large shadow economy potentially erodes the quality of institutions and people's appreciation for the state. Policymakers who lose credit may wish to use several strategies to limit the size of the shadow economy. In this sense, policymakers in countries with larger shadow economies have more incentives to adopt policies to delude the true burden of taxation compared to policymakers in countries with smaller shadow economies and a higher degree of tax compliance. In this way, policymakers may avoid a further increase of tax evasion and shadow economic activities. The available empirical evidence confirms our finding that countries with a higher level of fiscal illusion are often the ones with sizable shadow economies (see Table 1). An alternative interpretation may be that the shadow economy is just another form of fiscal illusion. In the presence of the shadow economy a difference exists between the official (average) tax burden and the real (average) tax burden. Honest taxpayers thus bear the burden paying too much taxes to compensate the loss of tax revenues through tax evasion and shadow economic activities, i.e., the individual tax burden for honest taxpayers is on average higher than what journalists, politicians and official statistics report. This view would also support the negative link between fiscal illusion and the shadow economy in the sense that both are substitutes, i.e. two sides of the same coin.

Table 3 shows the estimated direct (i.e. short run), indirect ${ }^{13}$ and total (i.e. long run) effects of the observed causal and latent variables for the most reliable MIMIC model specifications MIMIC 8-2-6.

\footnotetext{
${ }^{13}$ Indirect effects are calculated by multiplying the direct effects affecting each endogenous variable via other variables and considering the additional effects due to the cycle of mutual influence in feedback loop between the latent variables.
} 
Table 3: Direct, Indirect and Total Effect (MIMIC 8-2-6)

\begin{tabular}{|c|c|c|c|c|c|c|}
\hline \multirow[b]{2}{*}{ Causes } & \multicolumn{2}{|c|}{ Direct Effects } & \multicolumn{2}{|c|}{ Indirect Effects } & \multicolumn{2}{|c|}{ Total Effects } \\
\hline & $\begin{array}{l}\text { Shadow } \\
\text { Economy }\end{array}$ & $\begin{array}{l}\text { Fiscal } \\
\text { Illusion }\end{array}$ & $\begin{array}{l}\text { Shadow } \\
\text { Economy }\end{array}$ & $\begin{array}{l}\text { Fiscal } \\
\text { Illusion }\end{array}$ & $\begin{array}{l}\text { Shadow } \\
\text { Economy }\end{array}$ & $\begin{array}{l}\text { Fiscal } \\
\text { Illusion }\end{array}$ \\
\hline Shadow Economy & 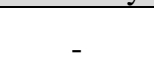 & $\begin{array}{l}0.41^{* * * *} \\
(5.84)\end{array}$ & $\begin{array}{c}-0.49^{\text {**** }} \\
(-5.84)\end{array}$ & $\begin{array}{l}-0.20^{* * * *} \\
(-5.84)\end{array}$ & $\begin{array}{l}-0.49^{* * * *} \\
(-5.84)\end{array}$ & $\begin{array}{l}0.21^{* * * *} \\
(5.84)\end{array}$ \\
\hline Fiscal Illusion & $\begin{array}{l}-2.38^{\text {***k }} \\
(-5.46)\end{array}$ & - & $\begin{array}{l}1.71^{* * * *} \\
(5.46)\end{array}$ & $\begin{array}{l}-0.49^{* * *} \\
(-5.46)\end{array}$ & $\begin{array}{l}-1.21^{* * * k} \\
(-5.46)\end{array}$ & $\begin{array}{l}-0.49^{* * * * k} \\
(-5.84)\end{array}$ \\
\hline Personal income tax & $\begin{array}{c}-0.59 \\
(-1.50)\end{array}$ & - & $\begin{array}{c}0.29 \\
(1.54)\end{array}$ & $\begin{array}{c}-0.12 \\
(-1.54)\end{array}$ & $\begin{array}{c}-0.30 \\
(-1.47)\end{array}$ & $\begin{array}{c}-0.12 \\
(-1.54)\end{array}$ \\
\hline $\begin{array}{c}\text { Corporate income } \\
\text { tax }\end{array}$ & $\begin{array}{l}-3.52^{\text {*3*k }} \\
(-3.37)\end{array}$ & - & $\begin{array}{l}1.73^{* * * *} \\
(3.66)\end{array}$ & $\begin{array}{l}-0.73^{\text {**** }} \\
(-3.86)\end{array}$ & $\begin{array}{l}-1.78^{* * * k} \\
(-3.09)\end{array}$ & $\begin{array}{l}-0.73^{* * * *} \\
(-3.86)\end{array}$ \\
\hline Unemployment rate & $\begin{array}{l}0.44^{* *} \\
(2.00)\end{array}$ & - & $\begin{array}{l}-0.21^{* *} \\
(-2.07)\end{array}$ & $\begin{array}{l}0.09^{* *} \\
(2.14)\end{array}$ & $\begin{array}{l}0.22^{*} \\
(1.92)\end{array}$ & $\begin{array}{l}0.09^{* *} \\
(2.14)\end{array}$ \\
\hline $\begin{array}{c}\text { Business Freedom } \\
\text { index }\end{array}$ & $\begin{array}{l}-0.43^{\text {*****1}} \\
(-3.40)\end{array}$ & - & $\begin{array}{l}0.21^{* * * *} \\
(3.74)\end{array}$ & $\begin{array}{l}-0.09^{* * * *} \\
(-3.87)\end{array}$ & $\begin{array}{l}-0.22^{\text {***3* }} \\
(-3.11)\end{array}$ & $\begin{array}{l}-0.09^{\text {***** }} \\
(-3.87)\end{array}$ \\
\hline Tax burden & $\begin{array}{l}1.17^{* * *} \\
(2.69)\end{array}$ & $\begin{array}{c}0.09 \\
(0.77) \\
\end{array}$ & $\begin{array}{l}-0.68^{* *} \\
(-2.25)\end{array}$ & $\begin{array}{l}0.20^{* * * *} \\
(2.92) \\
\end{array}$ & $\begin{array}{l}0.49^{* *} \\
(2.48)\end{array}$ & $\begin{array}{l}0.29^{* *} \\
(2.33)\end{array}$ \\
\hline $\begin{array}{l}\text { Self-employment } \\
\text { rate }\end{array}$ & $\begin{array}{c}0.01 \\
(0.13)\end{array}$ & $\begin{array}{c}-0.00 \\
(-0.05)\end{array}$ & $\begin{array}{c}-0.00 \\
(-0.05)\end{array}$ & $\begin{array}{c}0.00 \\
(0.14)\end{array}$ & $\begin{array}{c}0.10 \\
(0.14)\end{array}$ & $\begin{array}{c}0.00 \\
(0.05)\end{array}$ \\
\hline Top income tax rate & - & $\begin{array}{l}-0.48^{\text {**\%* }} \\
(-2.64)\end{array}$ & $\begin{array}{l}0.58^{* * *} \\
(2.41)\end{array}$ & $\begin{array}{l}0.24^{* * * * *} \\
(2.78)\end{array}$ & $\begin{array}{l}0.58^{* * *} \\
(2.41)\end{array}$ & $\begin{array}{l}-0.24^{\text {*** }} \\
(-2.50)\end{array}$ \\
\hline Secondary education & - & 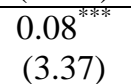 & $\begin{array}{l}-0.09^{\text {***** }} \\
(-3.18)\end{array}$ & $\begin{array}{l}-0.04^{* * * * 4} \\
(-3.65)\end{array}$ & $\begin{array}{l}-0.09^{\text {****⿲丶丶㇒木 }} \\
(-3.18)\end{array}$ & $\begin{array}{l}0.04^{\text {****** }} \\
(3.11)\end{array}$ \\
\hline
\end{tabular}

Notes: t-statistics are given in parentheses. ${ }^{*} \mathrm{p}<.1 ;{ }^{* *} \mathrm{p}<.05 ;{ }^{* * *} \mathrm{p}<.01$. Intercepts are omitted. The models have been estimated for an unbalanced panel of a cross-section of 104 countries over the period 1989 to 2009 (21 years).

To summarize: the estimated MIMIC models present empirical evidence supporting the hypothesis that a higher average tax burden directly increases the shadow economy $(+1.17)$ and hence encourages a government to adopt tax policies aimed at increasing the level of fiscal illusion $(+0.41)$. Combining these results with the negative effect of fiscal illusion on the shadow economy $(-2.38)$ and considering the feedback loop between the two latent variables to a stable long run equilibrium, we find that the total effect of an increase of the tax burden increases both shadow economic activities and fiscal illusion (i.e. total effects are 0.49 and 0.29 , respectively). An economic interpretation of this result may be that an increase of the tax burden causes a policy response, i.e. to implement fiscal illusion policies, which exceeds the citizen's incentives to participate in the shadow economy. Hence, policymakers overshoot with their policy response.

Furthermore, we find a positive total effect of the level of education on fiscal illusion $(+0.04)$. In this sense, the result supports the argument that a more educated society increases fiscal illusion as the government needs to implement more illusive policies to distort the taxpayers' perceptions about the true tax burden. The self-employment rate and the measure of the overall tax burden are not statistical different form zero. Regarding the indicators, i.e., the most common strategies to reduce citizens' perceptions of their true tax burden, we find the ratio of public debt to GDP to have the expected sign. The coefficient is also highly statistical significant. The estimated coefficient for the second indicator, the ratio of indirect to direct tax revenue supports the Mill hypothesis as the sign is as expected positive. Finally, the Herfindahl index of a tax and revenue system's complexity is not statistical significant. Although it seems plausible to assume governments designing more complicated and complex tax and revenue systems to increase the 
level of fiscal illusion and let taxpayers underestimate the true tax burden, we do not find empirical evidence for this hypothesis.

\section{Conclusion}

This paper aims to extend the empirical literature on the relationship between fiscal illusion and the shadow economy, making the attempt to simultaneously estimate both latent variables in a MIMIC model using a sample of 104 developed and developing countries. Our empirical results show that a higher tax burden positively contributes to the size of the shadow economy and indirectly incentivizes the government to increase the level of fiscal illusion. However, fiscal illusion policies need to be intensified the higher the educational level of citizens is on average. A lower top income tax rate, especially in rich economies with comprehensive welfare states and the need for considerable government revenues, may be an indication that governments do not honestly reveal the true tax burden. Hence, the level of fiscal illusion in such economies may be considered relatively high.. Most importantly, this paper presents for the first time a simultaneous analysis of the two latent variables shadow economy and fiscal illusion. The estimated coefficients of the relationship between them indicate that the shadow economy may positively impact fiscal illusion, that is, an increase of the shadow economy also leads to an increase of fiscal illusion. The reason may be a deterioration of the quality of institutions and attitudes towards the state. Policymakers may react to this trend using strategies to delude the true tax burden in order to deplete shadow economic activities. Alternatively, shadow economic activities may be just another form of fiscal illusion. Fiscal illusion though negatively impacts the shadow economy, meaning that higher levels of fiscal illusion decrease the shadow economy: Policymakers obviously aim to reduce the incentives for tax evasion and shadow economic activities through illusion, which is probably a common strategy mainly in rich countries having relatively sizable shadow economies. In those countries governments need to raise enough taxes to finance their comprehensive welfare states - they may keep revenues high by creating the illusion of a less burdensome tax system. Hence, governments face a Hobsons's choice: accepting larger shadow economies and lower tax revenues or systematically deluding taxpayers.

From a methodological viewpoint, the approach utilized in our paper underlines the complexity of the relationship between the two phenomena fiscal illusion and the shadow economy. In this sense, it highlights the need to apply systematic statistical approaches, such as MIMIC modeling techniques, to investigate the nature of these latent phenomena. 


\section{References}

Anderson J C Gerbing D W, 1984, "The effect of sampling error on convergence, improper solutions, and goodness-of-fit indices for maximum likelihood confirmatory factor analysis” Psychometrika 49 $155-173$

Bollen K A, Long J S, 1993, Testing structural equation models (Beverly Hills, CA: Sage).

Boomsma A, 1982, The robustness of LISREL against small sample sizes in factor analysis models. In Systems under indirect observation: Causality, structure, prediction (Part 1) Eds K J Jöreskog, H Wold (Amsterdam: North-Holland)

Boomsma A, 1985, "Nonconvergence, improper solutioms, and starting values in LISREL maximum likelihood estimation" Psychometrika 50 229-242

Browne, M. W. (1984). Asymptotically distribution-free methods for the analysis of covariance structures. British Journal of Mathematical and Statistical Psychology 37 1-21.

Brown T A, 2006, Confirmatory Factor Analysis for Applied Research (New York: Guilford Press)

Buchanan J M, 1967, Public finance in democratic process: fiscal institutions and individual choice, (Chapel Hill, USA University of North Carolina press)

Buehn A, Schneider F, 2012a, "Shadow economies around the world: Novel insights, accepted knowledge, and new estimates" International Tax and Public Finance 19 (1) 139-171

Buehn A, Schneider F, 2012b, "Corruption and the shadow economy: like oil and vinegar, like water and fire?" International Tax and Public Finance 19 (1) 172-194

Cabral M, Hoxby C, 2012, "The Hated Property Tax: Salience, Tax Rates, and Tax Revolts" NBER Working Paper 18514.

Chetty R, Looney A, Kroft K, 2009, "Salience and Taxation: Theory and Evidence” American Economic Review 99 (4) 1145-1177.

Chong A, Gradstein M, 2007, “Inequality and Informality” Journal of Public Economics 9 159-79

Congdon W J, Kling J R, Mullainathan S, 2009, "Behavioral Economics and Tax Policy" National Tax Journal 62 (3) 375-76.

Cullis J, Jones P, 1987, "Fiscal Illusion and Excessive Budgets: Some Indirect Evidence" Public Finance Quarterly 15 219-28

Dell'Anno R, 2007, "Shadow Economy in Portugal: an analysis with the MIMIC approach" Journal of Applied Economics 10 (2) 253-277

Dell'Anno R, 2008, "What is the relationship between Unofficial and Official Economy? An analysis in Latin American Countries" European Journal of Economics, Finance and Administrative Sciences 12 185-203 
Dell'Anno R, De Rosa V M, 2013, “The relevance of the theory of Fiscal Illusion. The case of the Italian tax system" History of Economic Thought and Policy 2 63-92.

Dell'Anno R, Dollery B, 2014, “Comparative fiscal illusion: A fiscal illusion index for the European Union” Empirical Economics 46 937-960

Dell'Anno R, Mourão P, 2012, "Fiscal Illusion around the World. An analysis using the Structural Equation Approach" Public Finance Review 40 (2) 270-299

Dreher, A, Kotsogiannis, C, McCorriston, S, 2009, "How do institutions affect corruption and the shadow economy?" International Tax and Public Finance 16 (6) 773-796

Dollery B E, Worthington A, 1996, "The Empirical Analysis of Fiscal Illusion" Journal of Economic Surveys 10 261-97

Duncan O D, 1975, Introduction to Structural Equation Models (New York: Academic Press)

Fasiani M, 1941, Principii di scienza felle finanze, vol. I. (Torino: Giappichelli Editore)

Feld L, Schneider F, 2010, "Survey on the Shadow Economy and Undeclared Earnings in OECD Countries" German Economic Review 11 (2) 109-149

Finkelstein A. 2009, “E-ZTax: Tax Salience and Tax Rates” The Quarterly Journal of Economics, 124 (3) 969-1010.

Jöreskog K G, Goldberger A, 1975, "Estimation of a model with multiple indicators and multiple causes of a single latent variable" Journal of the American Statistical Association 70 631-639

Kaufmann D, Kaliberda A, 1996, "Integrating the Unofficial Economy into the Dynamics of Post-Socialist Economies: A Framework of Analysis and Evidence" in B Kaminski (Ed) Economic Transition in the Newly Independent States (M.E. Sharpe Press. Armonk, New York)

McArdle J J, 1980, “Causal Modeling Applied to Psychonomic Systems Simulation” Behavior Research Methods \& Instrumentation 12 193-209

McArdle J J, McDonald R P, 1984, “Some Algebraic Properties of the Reticular Action Model” British Journal of Mathematical and Statistical Psychology 37234 -251

Mill J S, 1848, Principles of Political Economy (Consulted Edition: Mill, J. Stuart 1994. Oxford: Oxford University Press)

Mourão P. 2008. Towards a Puviani's Fiscal Illusion Index. Hacienda Publica Espanola 187(4) 49-86.

Oates W E, 1988, On the Nature and Measurement of Fiscal Illusion: A Survey. In G. Brennan et al., eds Taxation and Fiscal Federalism: Essays in Honour of Russell Mathews, pp. 65-82 (Sydney: Australian National University Press)

Olsson U H, Troye S V, Foss T, Howell R D 2000. "The performance of ML, GLS, and WLS Estimation in Structural Equation Modeling under conditions of Misspecification and Nonnormality", Structural Equation Modeling, 7(4) 557-595. 
Sausgruber R, Tyran J -R, 2005, “Testing the mill hypothesis of fiscal illusion” Public Choice 122 (1) 3968.

Schmölders G, 1960, Das Irrationale in der öffentlichen Finanzwirtschaft (Reinbeck: Rowohlt)

Schneider F, 2005, "Shadow economies around the world: What do we really know" European Journal of Political Economy 21 598-642

Schneider F, Enste D H, 2000, "Shadow economies: size, causes and consequences" Journal of Economic Literature 38 77-114

Schneider F, Buehn A, Montenegro C, 2010, "New Estimates for the Shadow Economies all over the World" International Economic Journal 24 (4) 443-461

Seater J J, 1993, “Ricardian Equivalence” Journal of Economic Literature 31 142-190

Stapleton D, 1978, "Analyzing political participation data with a MIMIC Model" Sociological Methodology 15 52-74

Steiger J H, Lind J C, 1980, Statistically-based tests for the number of common factors Paper presented at the annual Spring Meeting of the Psychometric Society in Iowa City. May 30, 1980

Tanzi V, 1999, "Uses and abuses of estimates of the underground economy” Economic Journal 109338 347

Wagner R, 1976, "Revenue structure, fiscal illusion and budgetary choice" Public Choice 25 45-61 


\section{Appendix: Data sources (1989-2009)}

\begin{tabular}{|c|c|c|c|c|c|c|}
\hline & Name & Source & Mean & Obs. & Min & Max \\
\hline $\mathbf{X}_{1}$ & $\begin{array}{l}\text { Personal Income } \\
\text { Tax }\end{array}$ & $\begin{array}{c}\text { Personal Income Tax to GDP; IMF GFS Database, OECD } \\
\text { Revenue Statistics, CEPAL }\end{array}$ & 5.16 & 1566 & 0.04 & 26.55 \\
\hline $\mathbf{X}_{2}$ & $\begin{array}{l}\text { Corporate Income } \\
\text { Tax }\end{array}$ & $\begin{array}{c}\text { Corporate Income Tax to GDP; IMF GFS Database, OECD } \\
\text { Revenue Statistics, CEPAL }\end{array}$ & 2.83 & 1633 & 0.01 & 19.80 \\
\hline $\mathbf{X}_{3}$ & Unemployment & Unemployment rate; WDI database & 8.30 & 1547 & 0.50 & 39.30 \\
\hline$X_{4}$ & $\begin{array}{l}\text { Business } \\
\text { Freedom }\end{array}$ & Business freedom; Heritage Foundation & 68.37 & 1494 & 30.80 & 100.0 \\
\hline $\mathbf{X}_{\mathbf{5}}$ & Tax Revenue & $\begin{array}{c}\text { Total Revenues to GDP; IMF GFS Database, OECD } \\
\text { Revenue Statistics, CEPAL }\end{array}$ & 29.38 & 1713 & 3.20 & 63.90 \\
\hline $\mathbf{X}_{6}$ & Self-Employment & $\begin{array}{c}\text { Total self-employed workers as a proportion of total } \\
\text { employment; WDI }\end{array}$ & 28.33 & 1370 & 2.20 & 95.50 \\
\hline $\mathbf{X}_{7}$ & $\begin{array}{l}\text { Top personal } \\
\text { income tax rate }\end{array}$ & $\begin{array}{c}\text { Top statutory PIT rate (\%); World Tax Indicators, } \\
\text { International Center for Public Policy }\end{array}$ & 35.49 & 1604 & 0.00 & 75.00 \\
\hline $\mathbf{X}_{\mathbf{8}}$ & Education & School enrolment, secondary (\% gross); WDI & 78.75 & 1718 & 4.47 & 161.8 \\
\hline $\mathbf{Y}_{1}$ & Labor force part. & Labor force participation rate; WDI & 62.67 & 2184 & 43.70 & 90.80 \\
\hline $\mathbf{Y}_{2}$ & Growth GDP & GDP per capita growth, annual (\%); WDI & 1.80 & 2163 & -45.3 & 22.55 \\
\hline $\mathbf{Y}_{3}$ & Currency ratio & M0 over M1; IMF - International Financial Statistics & 2.03 & 1774 & 0.00 & 349.6 \\
\hline $\mathbf{Y}_{4}$ & $\begin{array}{c}\text { Normalized } \\
\text { Herfindahl Index } \\
\text { of Revenue }\end{array}$ & $\begin{array}{l}\left\{\left[\text { Taxes on goods and services }(\% \text { of revenue })^{2}+\text { taxes on }\right.\right. \\
\text { income }(\% \text { revenue })^{2}+\text { social security contributions }(\% \\
\left.\text { revenues })^{2}+\text { other taxes }(\% \text { of revenue })^{2}\right]+[100-(\text { Taxes } \\
\text { on goods and services }(\% \text { of revenue })+\text { taxes on income }(\% \\
\text { revenue })+ \text { social security contributions }(\% \text { revenues })+ \\
\left.\left.\text { other taxes }(\% \text { of revenue })]^{2}-1 / 5\right)\right\} /[10000-(1 / 5)] ; \text { WDI }\end{array}$ & 0.36 & 1314 & 0.22 & 0.99 \\
\hline $\mathbf{Y}_{5}$ & Public Debt & Central government debt, total (\% of GDP); WDI & 58.18 & 866 & 0.00 & 289.8 \\
\hline $\mathbf{Y}_{6}$ & $\begin{array}{l}\text { Indirect Tax / } \\
\text { Direct Tax }\end{array}$ & $\begin{array}{l}\text { Ratio of indirect and direct tax revenues (i.e., ratio of taxes } \\
\text { on goods and services / taxes on income, profits and capital } \\
\text { gains); WDI }\end{array}$ & 1.88 & 1308 & 0.00 & 52.41 \\
\hline
\end{tabular}

List of countries: Australia, Austria, Bangladesh, Belgium, Belize, Benin, Bhutan, Bolivia, Brazil, Bulgaria, Burkina Faso, Burundi, Canada, Chile, China, P.R., Hong Kong, Colombia, Congo Dem. Rep., Congo Rep., Costa Rica, Côte d'Ivoire, Croatia, Cyprus, Czech Republic, Denmark, Dominican Republic, Ecuador, Egypt, El Salvador, Estonia, Ethiopia, Fiji, Finland, France, Georgia, Germany, Greece, Guatemala, Honduras, Hungary, Iceland, India, Indonesia, Iran, Ireland, Israel, Italy, Jamaica, Japan, Jordan, Kazakhstan, Kenya, Korea S., Kuwait, Latvia, Lesotho, Lithuania, Luxembourg, Madagascar, Malaysia, Malta, Mauritius, Mexico, Moldova, Mongolia, Morocco, Namibia, Nepal, Netherlands, New Zealand, Nicaragua, Norway, Oman, Pakistan, Panama, Paraguay, Peru, Philippines, Poland, Portugal, Romania, Russia, Senegal, Sierra Leone, Singapore, Slovak Republic, Slovenia, South Africa, Spain, Sri Lanka, Swaziland, Sweden, Switzerland, Syrian Arab Republic, Thailand, Trinidad and Tobago, Tunisia, Turkey, Uganda, Ukraine, United Kingdom, United States, Uruguay, Venezuela, Zimbabwe. 